\title{
Data-driven based logistic function and prediction- area plot for mineral prospectivity mapping: a case study from the eastern margin of Qinling orogenic belt, central China
}

\section{Hongyang Bai}

China University of Mining and Technology

\section{Yuan Cao}

Henan Bureau Of Geology And Mineral Exploration And Development

Heng Zhang

Henan Bureau Of Geology And Mineral Exploration And Development

Wenfeng Wang ( $\nabla$ wangwenfeng@cumt.edu.cn )

China University of Mining and Technology https://orcid.org/0000-0002-2200-0250

Chaojun Jiang

Henan Bureau Of Geology And Mineral Exploration And Development

\section{Yongguo Yang}

China University of Mining and Technology

\section{Research Article}

Keywords: Data-driven, Logistic function, Prediction-area plot, Mineral prospectivity mapping, Qinling 0orogenic belt.

Posted Date: June 23rd, 2021

DOI: https://doi.org/10.21203/rs.3.rs-306330/v1

License: (c) (1) This work is licensed under a Creative Commons Attribution 4.0 International License. Read Full License 
1 Data-driven based logistic function and prediction-area plot for mineral prospectivity mapping: a case study from the eastern margin of Qinling orogenic

3 belt, central China

4 Hongyang Bai ${ }^{\mathrm{a}, \mathrm{c}}$, Yuan Cao ${ }^{\mathrm{b}}$, Heng Zhang ${ }^{\mathrm{b}}$, Wenfeng Wang ${ }^{\mathrm{a}, \mathrm{c}, \mathrm{d}, *}$, Chaojun Jiang ${ }^{\mathrm{b}}$, Yongguo Yang ${ }^{\mathrm{a}, \mathrm{c}}$

$5 \quad$ a School of Resources and Geosciences, China University of Mining and Technology, Xuzhou 221116, China

$6{ }^{b}$ The Second Geology Prospecting Institute of Henan Bureau of Geology and Mineral Exploration and Development, Zhengzhou 451464,

$7 \quad$ China

$8{ }^{c}$ Key Laboratory of Coalbed Methane Resources and Reservoir Formation Process of the Ministry of Education, China University of

9 Mining and Technology, Xuzhou 221000, China

$10{ }^{d}$ School of Geology and Mining Engineering, Xinjiang University, Urumqi 830047, China

11 Abstract

12 The present work combines data-driven based logistic function with prediction-area plot for delineating target areas of orogenic gold deposits in eastern margin of Qinling metallogenic belt, central China. Firstly, the values of geological and geochemical information layer were transformed into a series of fuzzy numbers with a range of 0-1 through a data-driven based logistic function on the basis of mineralization theory of the orogenic gold deposits. Secondly, the prediction-area(P-A) plot was performed on the above evidence layers and their corresponding fuzzy overlay layers to pick out a proper prediction scheme for mineral prospectivity mapping(MPM) based on the known gold occurrences. What's more, to further prove the advantages of this method, we also used a knowledge-driven approach for comparison purpose. Finally, with the concentration-area(C-A) fractal model, the fractal thresholds were determined and a mineral prospecting map was generated. The result, five of the six known gold

\footnotetext{
* Corresponding author at: School of Resources and Geosciences, China University of Mining and Technology, Xuzhou 221116, China. E-mail address: wenfwang@vip.163.com.
} 
$43 \%$ of the study area), confirmed the joint application of data-driven based logistic function and prediction-area plot a simple, effective and low-cost method for mineral prospectivity mapping, which can be a guidance for further work in the research area.

Keywords: Data-driven; Logistic function; Prediction-area plot; Mineral prospectivity mapping; Qinling orogenic belt.

\section{Declarations}

Funding: This study was supported by the National Natural Science Foundation of China (Nos. U1903207, 41972176 and 41872248) as well as A Project Funded by the Priority Academic Program Development of Jiangsu Higher Education Institutions.

Conflicts of interest: No conflict of interest exits in the submission of this manuscript, and manuscript is approved by all authors for publication.

Availability of data and material: All data generated or analyzed during this study are included in this article.

Code availability: Not applicable.

\section{Introduction}

Mineral prospectivity mapping is a comprehensive research, during which geological engineers depict metallogenic target areas with known information and data in the study area to guide further exploration. It is essentially a classification technique (Yousefi and Carranza, 2015a), by which the study area could be divided into areas with high, moderate and low favorability of mineralization, respectively (Knox-Robinso, 2000; Abedi, 2012). Simply, its objective is to portray the smallest area where usually contains the most mineral deposits in the study area. In the above process, however, two key difficulties remain yet. One is to convert evidence layers with different orders of magnitude values into a same space and integrate them (Yousefi and Nykänen, 2016), the other is to determine a group of reasonable thresholds to demarcate the study area(Knox-Robinso, 2000). 

be grouped into three categories(Yousefi and Nykänen, 2016; Yousefi and Carranza ,2016; Du et al., 2016). One is the knowledge-driven method, which mainly assess mineralization evidences based on the

knowledge of geological experts and assigns different weights to each mineralization factor. It is generally suitable for study areas with low exploration levels(Carranza, 2010), in which a large amount of mineralization data is absent. Among them, fuzzy sets and fuzzy logistic, proposed by Zadeh (1965), has been widely applied and proved of great value in MPM by lots of geologists (An, 1991; Cheng and Agterberg, 1999; Knox-Robinson, 2000; Carranza and Hale, 2001; Luo and Dimitrakopoulos, 2003; Nykänen, 2008; Lusty, 2012; Abedi, 2013; Ford et al., 2016; Du et al., 2016). However, the method has a weakness of suffering the experts' bias, thus, leading to the result that different experts often have different opinions(Yousefi and Carranza, 2015a). Another is the traditional data-driven method, which can better establish the relationship between known mines and various evidence layers for metallogenic prediction(Porwal et al. 2003a, b; Carranza, 2008; Carranza et al., 2008a; Zuo, 2011; Liu et al. 2014, 2015). Nevertheless, its deficiency, requires a batch of known mines training to establish this connection, leading it infeasible in areas with low exploration levels. As a result, it would be deviation from the fact as unknown deposits have a lesser chance to participate in such training. Besides, there are also approaches(or system) of integration (Yousefi et al., 2019) or hybridization of the two aforementioned methods(Chung and Fabbri, 1993; Billa et al., 2004; Porwal et al., 2004, 2006; Roy et al., 2006; Carranza et al., 2008b; Cassard et al., 2008).Whereas, most of whom still cannot get out of the above dilemma or just in development (eg. exploration information system promoted by Yousefi et al.)

In order to solve these problems, many geologists attempted not to use training points to assign weights to evidence layers(Luo, 1990; Chung and Fabbri, 1993; Carranza and Hale, 2002; Luo and 
Dimitrakopoulos, 2003; Carranza, 2010).However, their choice of experience functions are also depend on expert judgment, leading them to suffer the same limitations as knowledge-driven or data-driven methods.

Recently, a data-driven approach based on logistic functions proposed by Yousefi et al.(2012, 2013, 2014) and Yousefi and Carranza (2015a) could well overcome the defects of the above two methods. It assigns weights to the evidence layers in a data-driven way without experts' bias and without using the known mines. In this paper, the logistic function is applied to convert the evidence values into fuzzy values with the range of 0-1. Whereafter, the P-A plot advocated by Yousefi and Carranza(2015a, 2015b, 2016)was applied to evaluate the prediction ability and fuzzy overlay was used to integrate these fuzzy layers to generate a prospective map. Consequently, three prospective maps were obtained and assembled and the best one was identified. Finally, a prospectivity map was obtained by means of concentration area (C-A ) model classification. With 5 out of 6 known Au occurences predicted in 18.6 percent of the study area, a satisfactory prospectivity map was obtained. It should be noted that all the aforementioned spatial analyses were based on the raster format in geographical information system (GIS).

\section{Geological Setting}

The study area lies on the southwest of Henan province, central China, covering an area about $1001 \mathrm{~km}^{2}$. It is located tectonically in the junction between the southern margin of the north China plate and the northern margin of the Yangtze Plate (the central and eastern part of the Qinling structural belt), with Jingziguan-Shigang complex syncline, Xixia fault depression basin generated (Meng and Zhang, 2000; Bureau of geology and mineral resources of Henan province, 1989). Crossing four metallogenic zones (north Qinling orogenic belt, south Qinling fold belt, Xixia-Tongbai polymetallic metallogenic belt and the Danjiangkou gold-silver-vanadium-antimony metallogenic zone), the study area is characterized 
by complex geological conditions, frequent magmatic activities, and significant structural deformation-

(regional) metamorphic effects. Consequently, the metallogenic geological conditions are superior, with

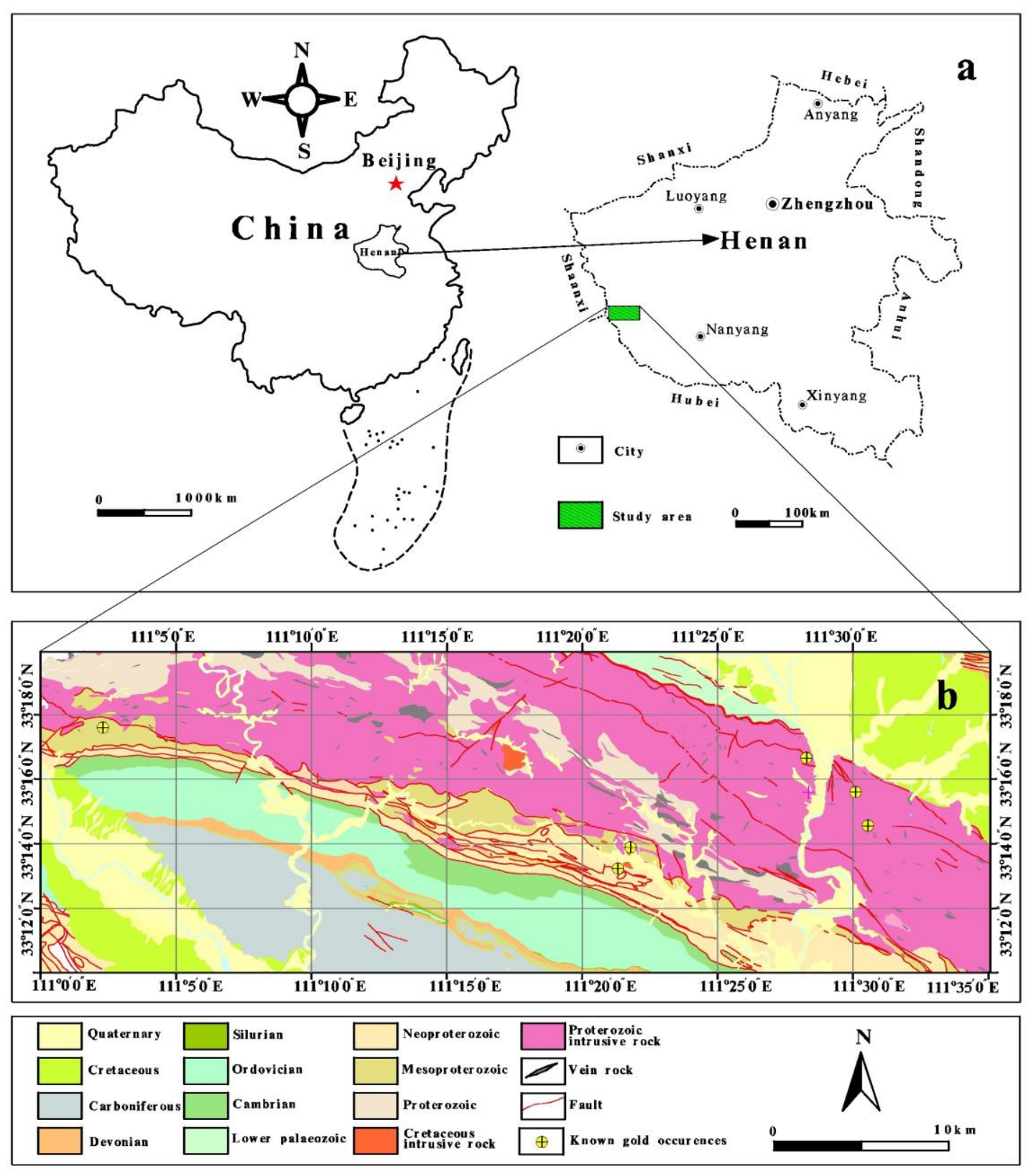

Fig.1. (a)Location of the study area and (b)brief geological map of the study area(modified from Bureau of geology and mineral resources of Henan province, 1989). 
In this paper, we used the 1: 50000 regional geological map and 1: 50000 stream sediment survey prepared by the second geology prospecting institute of Henan bureau of geology and mineral exploration and development. A total of 4036 samples were collected, processed and analyzed with a sampling density of 4-6 points per square kilometer in about 1000 square kilometers in the study area. Each of the original samples weighed more than $150 \mathrm{~g}$ with a particle size less than 60 mesh $(<216 \mu \mathrm{m})$. for $\mathrm{Cu}, 1 \mathrm{ppm}$ for $\mathrm{Pb}, 5 \mathrm{ppm}$ for $\mathrm{Zn}, 0.3 \mathrm{ppm}$ for $\mathrm{Mo}, 0.3 \mathrm{ppm}$ for $\mathrm{W}, 0.04 \mathrm{ppm}$ for $\mathrm{Cd}$. Management (DZ01304-2006).

\subsection{Data preprocessing} the evidence maps. Subsequently, the geological data and geochemical data were processed to obtain evidence values in each cell. In this way, the study area contains a total of 25,024 cells. 
et al., 2000; Goldfarb et al., 2001). At the same time, as its ore-bearing rocks could not be more complex

and diverse, a variety of rocks can generate ore-bearing rocks when other mineralization conditions are in place. As a result, only ore-controlling structures and magmatic activities are considered in actual research in this paper.

On the basis of 1:50,000 geology survey, the main geological information related to the mineralization, such as magmata and faults, were extracted as the evidence layers. Meanwhile, based on the measurement of 1:50,000 stream sediment survey, Stage Factor Analysis (SFA) was performed to carry out the multi-element closely related to the gold mineralization in the study area. Subsequently, the corresponding multi-element factor were grid-processed to get their value in each cell.

\subsubsection{Geological evidences, mainly heat sources and faults.}

Magma, as the main heat source, takes an important role in the formation of gold deposits. It can not only provide corresponding motive force for element migration and aggregation, but also supply the matter source(Craw et al., 2006). As Mao et al.(2002) and chen et al.(2008)mentioned, most gold deposits are related to Mesozoic granites in Xiaoqinling-Xiong'ershan region. In this paper, the granite vein and the Yanshanian granite porphyry were extracted as the evidence layers and the distance from the intrusive contact was used as the indicator criterion. However, the further from the intrusive, the less the possibility of mineralization, thus, the inverse square of the distance from intrusive was taken as the evidence value in each cell (Fig. 2a). It is generally accepted that faults are important channels for the movement of geological fluids (Pirajno, 2010). Without faults, there could be little migration and enrichment of elements, as a result, impossible to generate gold deposits as well. Consequently, we take proximity to fault as the evidence value, whose acquisition way is similar to that of heat source(Fig. 2b). 
143 2014) as an optimized method, was performed on 4036 samples of 10 elements to obtain multi-element

144 geochemical anomalies factors based on statistical product and service solutions (SPSS) platform.

\section{Table 1}

146 Rotated factor matrix of staged factor analysisor data of samples from the study area. Loadings in bold

147 represent the selected elements based on threshold of 0.6 (the absolute threshold value) for each stage.

\begin{tabular}{|c|c|c|c|c|c|c|c|c|c|}
\hline \multicolumn{6}{|c|}{ First main phase } & \multicolumn{4}{|c|}{ Second main phase } \\
\hline \multicolumn{3}{|c|}{ First stage } & \multicolumn{3}{|c|}{ Second stage } & \multicolumn{2}{|c|}{ Third stage } & \multicolumn{2}{|c|}{ Fourth stage } \\
\hline Element & $\mathrm{F} 1$ & $\mathrm{~F} 2$ & Element & $\mathrm{F} 1$ & $\mathrm{~F} 2$ & Element & $\mathrm{F} 1$ & Element & $\mathrm{F} 1$ \\
\hline $\mathrm{Au}$ & -0.1 & 0.726 & $\mathrm{Au}$ & -0.07 & 0.719 & $\mathrm{Cu}$ & 0.698 & $\mathrm{Au}$ & 0.681 \\
\hline $\mathrm{Ag}$ & 0.48 & 0.592 & As & 0.153 & 0.803 & $\mathrm{Zn}$ & 0.797 & As & 0.819 \\
\hline As & 0.118 & 0.785 & $\mathrm{Cu}$ & 0.719 & -0.029 & Mo & 0.758 & $\mathrm{~Pb}$ & 0.783 \\
\hline $\mathrm{Sb}$ & 0.184 & 0.304 & $\mathrm{~Pb}$ & 0.291 & 0.713 & $\mathrm{Cd}$ & 0.838 & & \\
\hline $\mathrm{Cu}$ & 0.723 & -0.002 & $\mathrm{Zn}$ & 0.72 & 0.384 & & & & \\
\hline $\mathrm{Pb}$ & 0.257 & 0.685 & Mo & 0.771 & 0.072 & & & & \\
\hline $\mathrm{Zn}$ & 0.692 & 0.354 & $\mathrm{Cd}$ & 0.812 & 0.16 & & & & \\
\hline Mo & 0.761 & 0.1 & & & & & & & \\
\hline W & 0.266 & 0.235 & & & & & & & \\
\hline $\mathrm{Cd}$ & 0.803 & 0.195 & & & & & & & \\
\hline
\end{tabular}



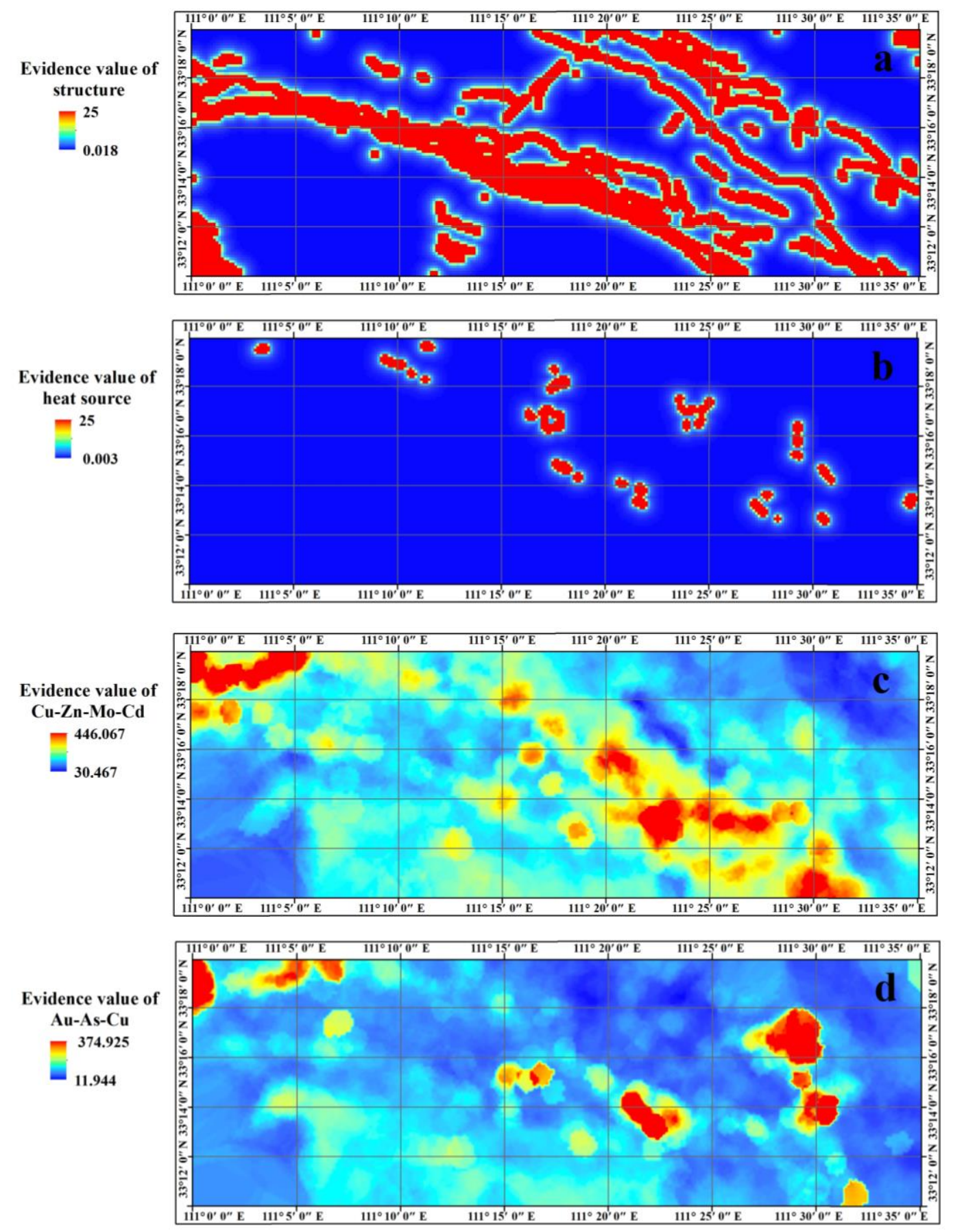

Fig.2. Evidence values of (a) structure; (b) heat source; (c) $\mathrm{Cu}-\mathrm{Zn}-\mathrm{Mo}-\mathrm{Cr}$ factor and (d) Au-As-Pb factor.

\section{Method and result}



proxies of the evidence values.

$$
\mathrm{F}_{\mathrm{EV}}=\frac{1}{1+e^{-s(E V-\mathrm{i})}}
$$
or concentrated fuzzy numbers, thus, resulting in the fuzzy score a poor representative of the source data. avoids the distortion of conversion caused by subjective bias of experts. 
For Orogenic gold deposits, faults are usual play a role of activity space or even storage space for ore-containing hydrotherm (Groves et al., 2000; Herbert et al., 2014; Carranza et al., 2015). It is generally believed that the further from the fault, the lower the degree of profitability of the mineralization, so the inverse square of proximity to fault is applied as the evidence value. When the evidence value is 0 (the cell contains the fault itself), its inverse square does not exist, so we manually assign it the maximum value. Based on the GIS platform, proximity to fault of each cell is computed, and the maximum and and (3), the corresponding s and $\mathrm{i}$ is acquired as 0.3683 and 12.5090 . Proximity to intrusive is used as the data set of heat source. Since the further from the intrusive contact, the lower the degree of profitability of the mineralization, we applied the inverse square as the evidence value as well. For the nonuniformity of sampling points, the ordinary kriging interpolation method was conducted on the two multi-element ( $\mathrm{Cu}-\mathrm{Zn}$-Mo-Cd factor and $\mathrm{Au}-\mathrm{As}-\mathrm{Pb}$ factor) to obtain the evidence value of each cell on the basis of verifying that they conform to the normal distribution. 2 and the obtained fuzzy score layers are revealed in Fig.3.

\section{Table 2}


Evidential layer

i

Structure

0.3683

12.5090

Heat source

0.3680

12.5015

Cu-Zn-Mo-Cd-

0.0221

238.2672

$\mathrm{Au}-\mathrm{As}-\mathrm{Pb}$

0.0253

193.4347
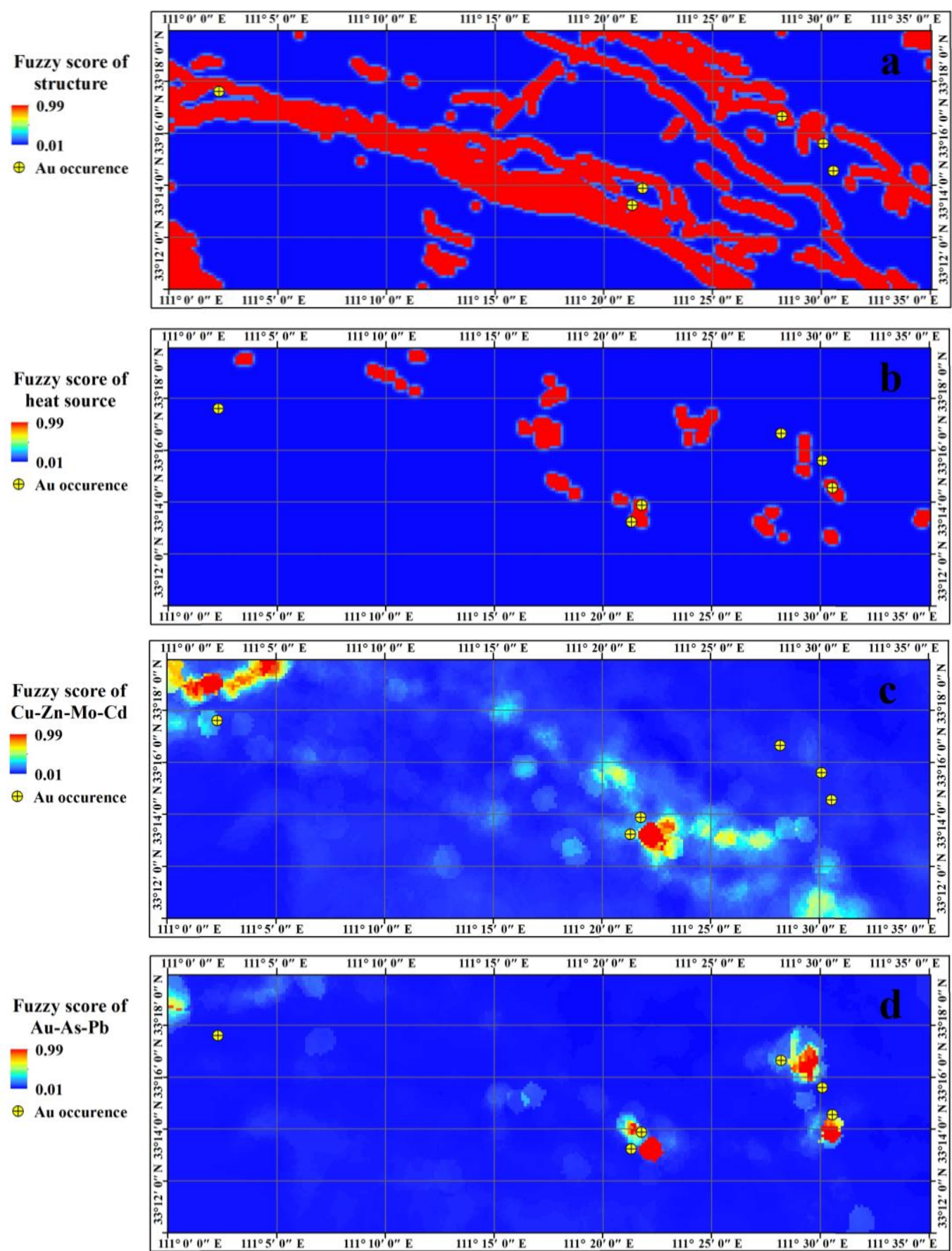
Fig.3. Fuzzy score of: (a)structuret; (b)heat source; (c) Cu-Zn-Mo-Cd factor and (d) Au-As-Pb factor.

In order to check whether the fuzzy score could be a good representation of the mineralization the relative importance.
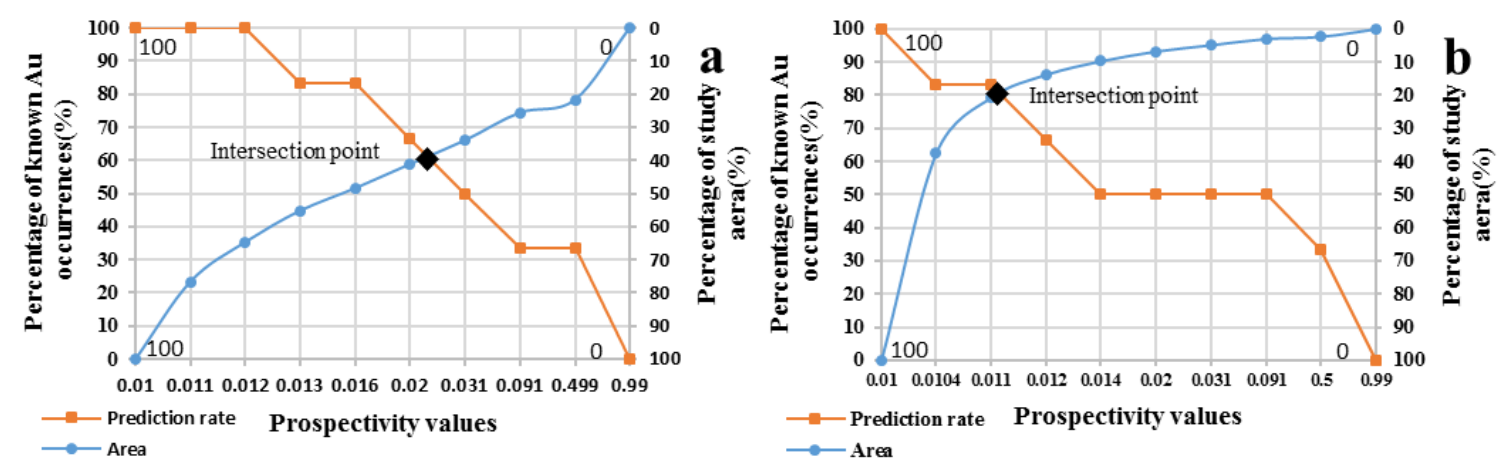

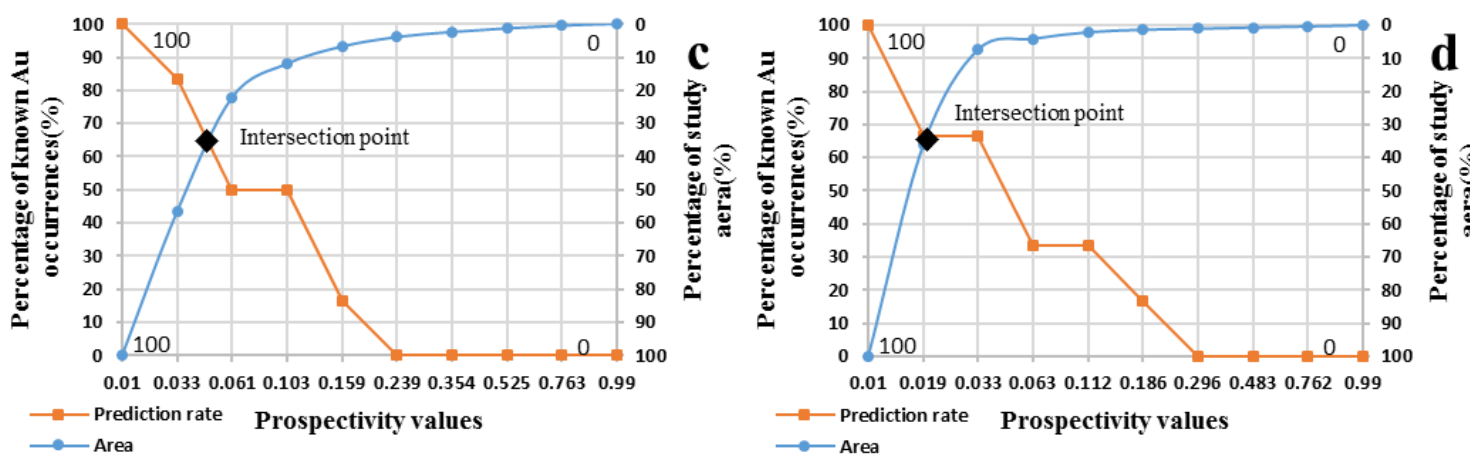

217 Fig.4. Prediction rate-Area(P-A) plot of each layer: (a)structure; (b)heat source; (c) Cu-Zn-Mo-Cr factor and (d) $\mathrm{Au}-\mathrm{As}-\mathrm{Pb}$ factor.

The P-A plot of evidence layer were shown in Fig.4.The intersection of the two curves represents

the prediction ability of the evidence layer. The higher the intersection, the stronger the prediction ability,

and the closer it is to mineralization.

\subsection{Integration}

As can be seen from Table 3, the prediction capability of each fuzzy evidence layers was quite

different. The best one is the heat source, with a value of 81 , significantly exceeds other layers. In order

to better find out the relationship between each fuzzy evidence layer and mineralization, we conducted

\section{Table 3}

228 Prediction ability of each evidence layers.

\begin{tabular}{lcc}
\hline Evidential layer & \% of known Au occurrences & \% of study area \\
\hline Fig.3a (structure) & 61 & 39 \\
Fig.3b (heat source) & 81 & 19 \\
Fig.3c ( Cu-Zn-Mo-Cr $)$ & 65 & 35 \\
Fig.3d ( Au-As-Pb $)$ & 67 & 33 \\
\hline
\end{tabular}


230 integrated separately to obtain 3 overlay maps (Fig.5), which were then estimated by P-A plot and their evaluation results are shown in Table 4.
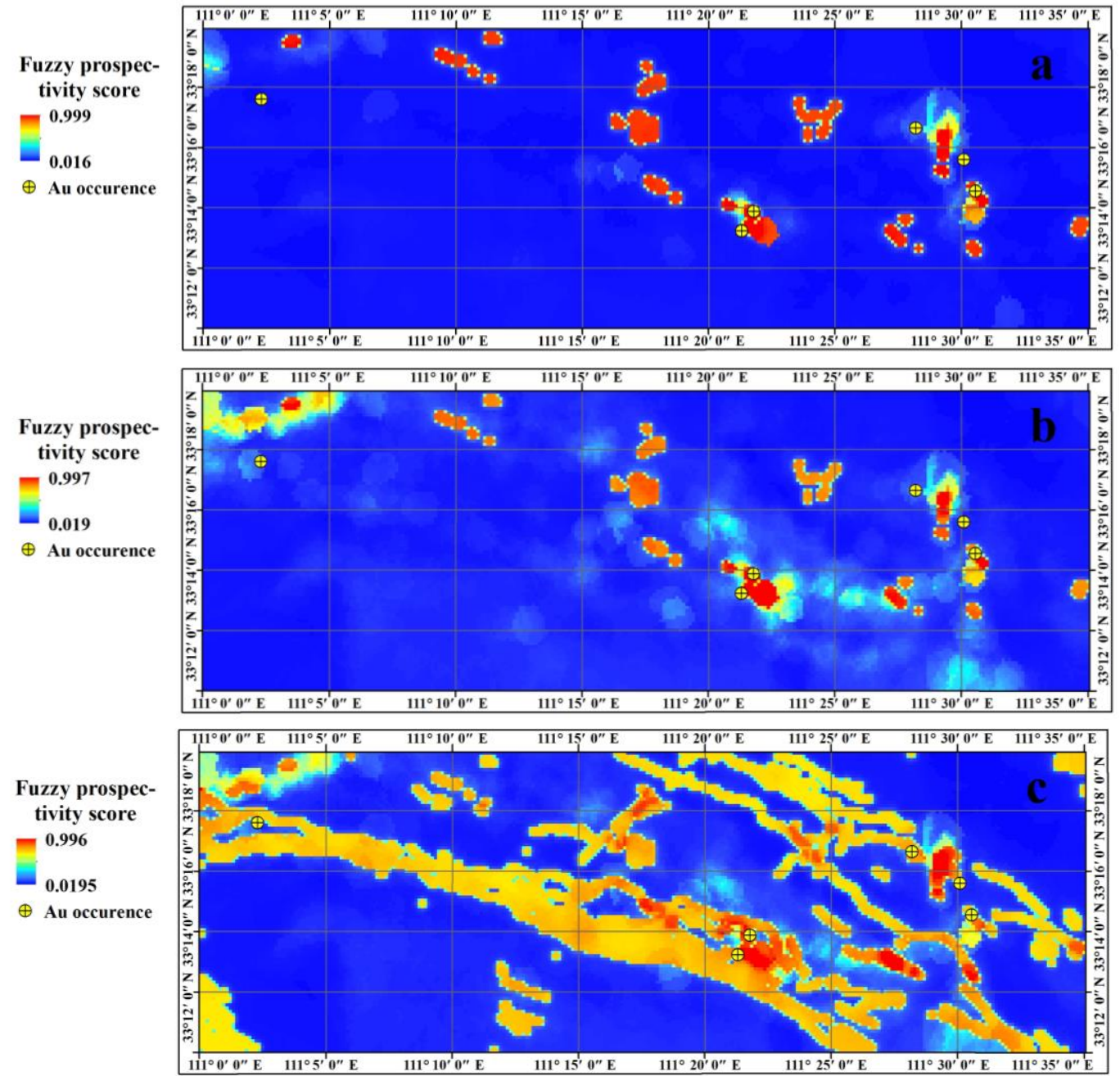

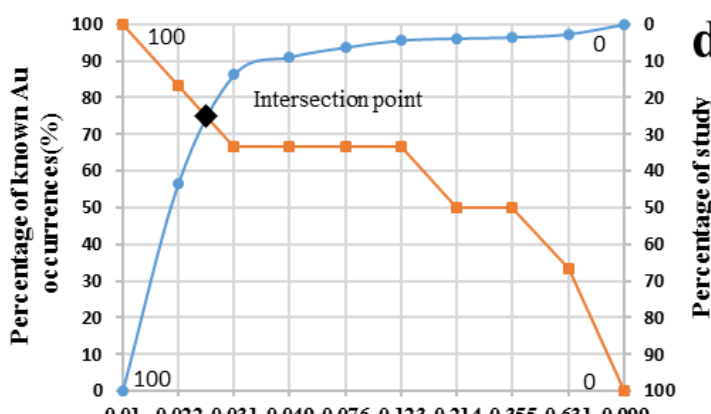

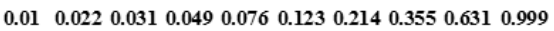

- - Prediction rate Prospectivity values

$$
\longrightarrow \text { Area }
$$

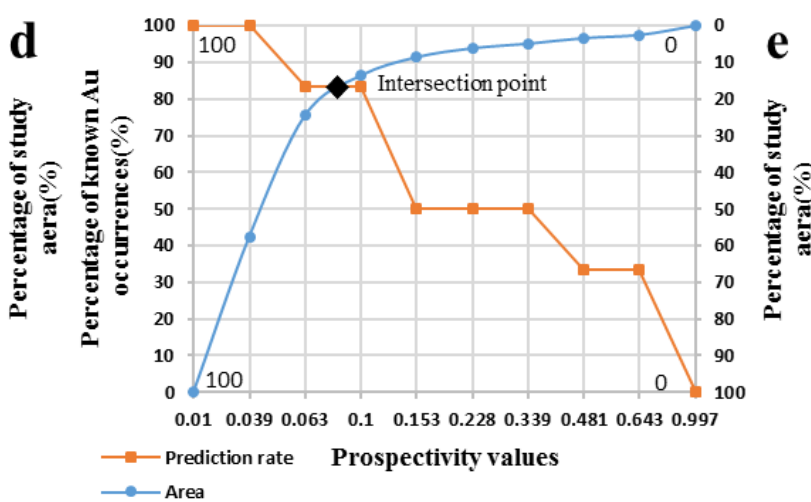




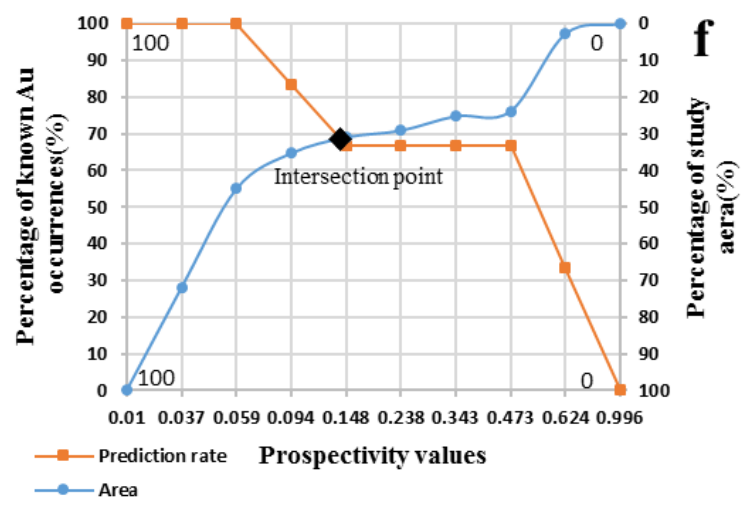

Fig.5. Perspectivity score of (a) integrated by Fig.3b and 3d, (b) integrated by Fig.3b, 3d and 3c, and (c) integrated by Fig.3b, 3d, 3c and 3a as well as P-A plot of Fig.5a, 5b and 5c. predictive value Fig.5d, 5e and Table 4). However, we also noticed that the corresponding forecasting capacity from Fig. $5 \mathrm{~d}$ to $5 \mathrm{f}$ possessed a trend of increasing first and then declining. Among them, Fig.5e reached a maximum with a prediction rate of $84 \%$, at this point, the evidence layers for integration were Fig. $3 \mathrm{~b}, 3 \mathrm{c}$ and $3 \mathrm{~d}$ with prediction rate of $81 \%, 65 \%$ and $67 \%$, respectively. This phenomenon is weird, because several layers with lower prediction ability have a better result when integrated. In spite of this,

240 it is in line with previous study (Yousefi, 2015). What is interesting is that the prediction rate of Fig.5c

241 dropped significantly when fault is added for integrating. This may be caused by the multi-phase superposition of tectonic movements in this area, leading to the development of a large number of faults,

243 while there is no magmatic hydrothermal activity in some faults.

\section{Table 4}

245 Prediction ability of each integrated layers.

\begin{tabular}{lll}
\hline Fuzzy prospectivity map & $\%$ of known Au occurrences & $\%$ of study area \\
\hline Fig.5a & 75 & 25 \\
Fig.5b & 83 & 17
\end{tabular}


most important factors in the mineralization process. Consequently, the corresponding Fig. $5 \mathrm{~b}$ could be used as the ideal perspectivity map in the study area.

\subsection{Fuzzy prospectivity score obtained in knowledge-driven way}
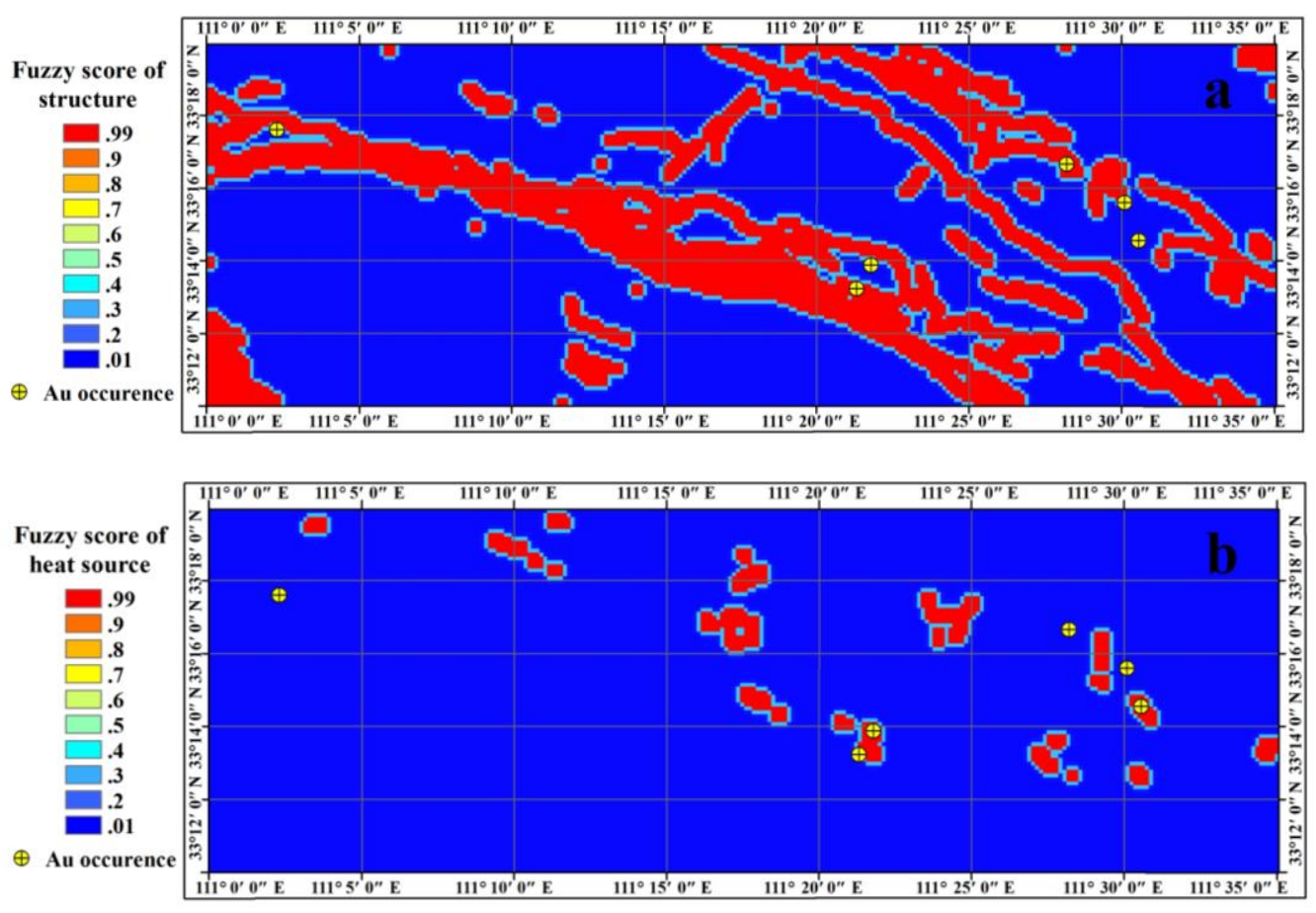

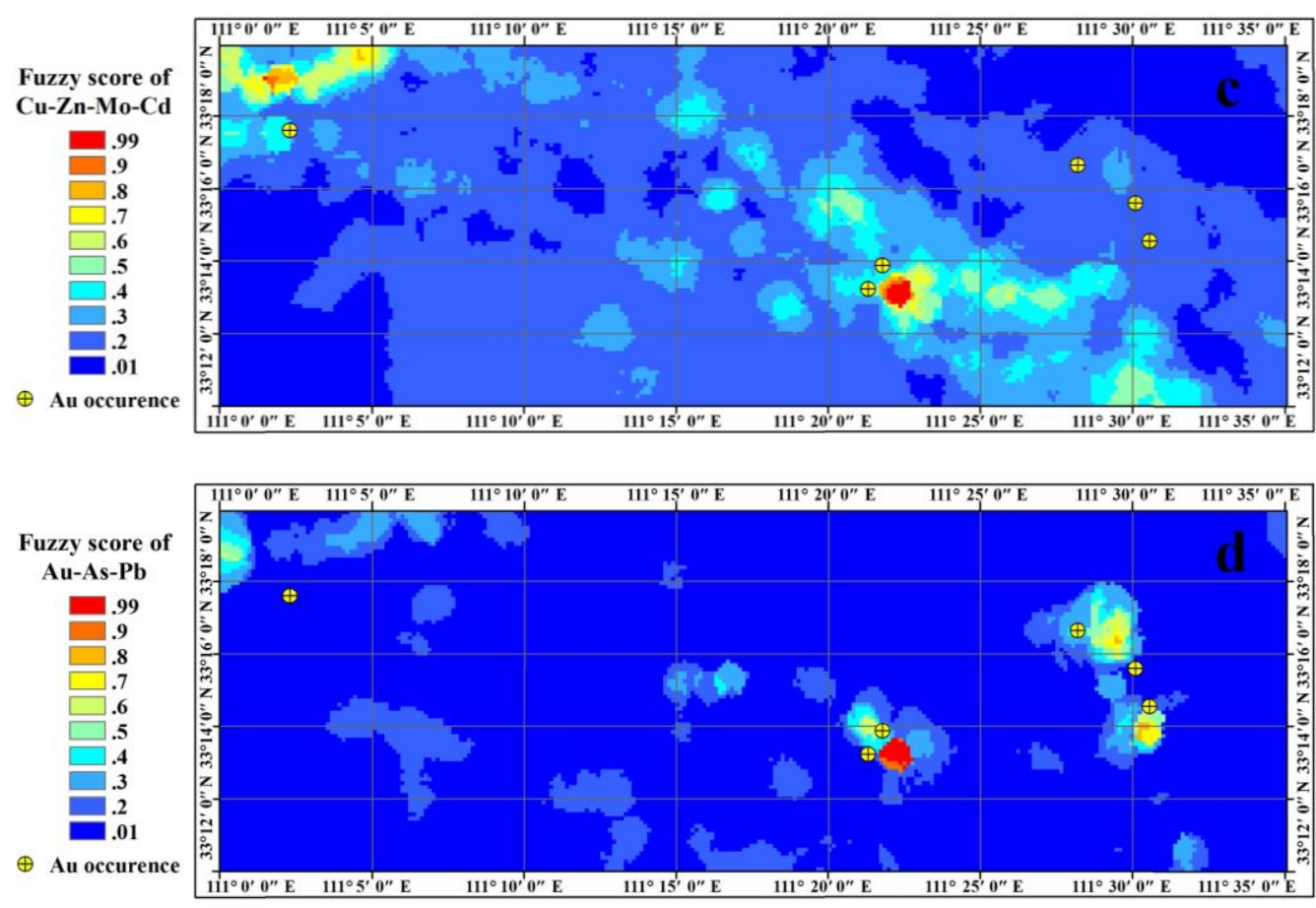

Fig.6. Fuzzy score obtained by knowedge-driven way: (a) structure; (b)heat source; (c) $\mathrm{Cu}-\mathrm{Zn}-\mathrm{Mo}-\mathrm{Cr}$

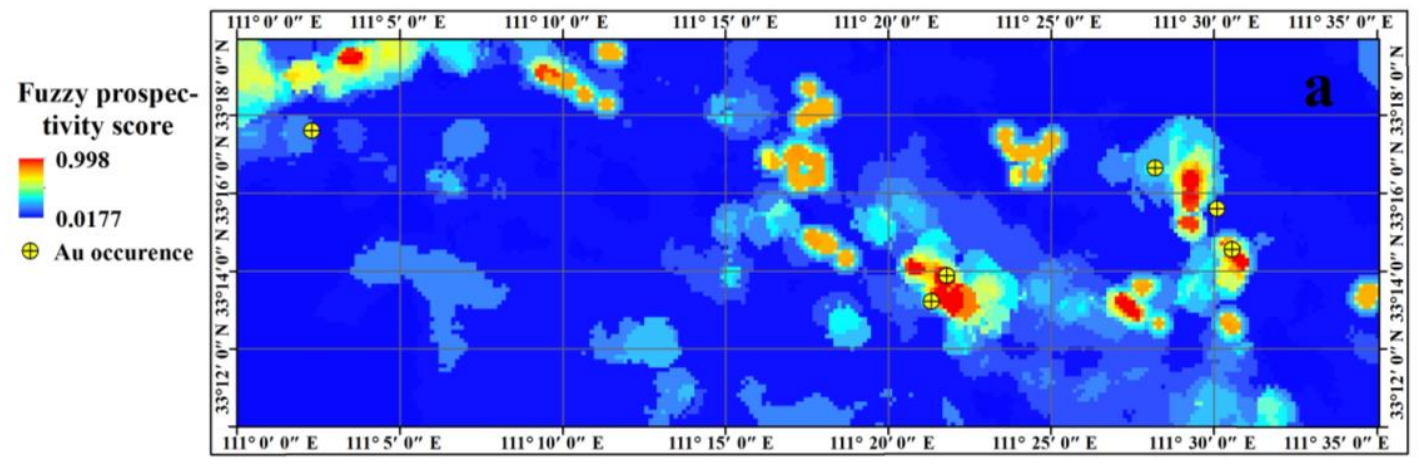




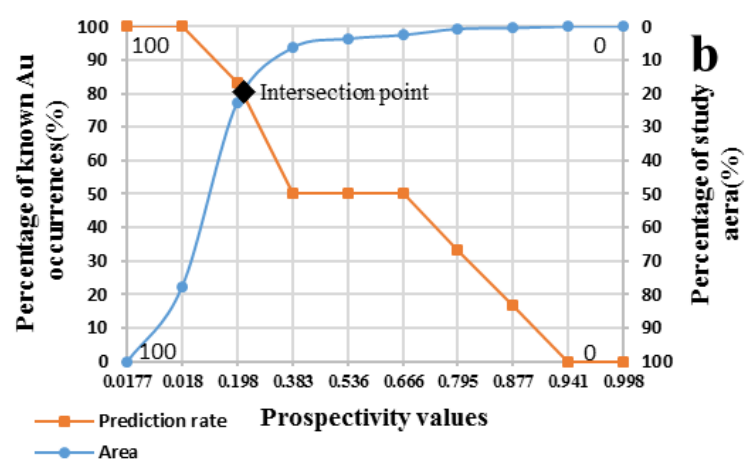

265 Fig.7. (a) Fuzzy prospectivity score integrated by Fig 6b, 6c and 6d; (b) P-A plot of Fig.7a.

\subsection{To determine the thresholds}

As Mandelbrot, B.B.(1962,1983,1985) and Carlson(1991) mentioned, in many cases, ore deposits are

characterized by aggregation and fractal distribution. Therefore, in order to figure out the high, moderate,

Fig. $5 \mathrm{~b}$ so as to obtain a prospectivity map. This method was proposed by Cheng (1994) and has been

value corre sponding to the fractal point could be used as the threshold for differentiating the favorable, unfavorable and intermediate areas of mineralization (Yousefi and Nykänen, 2016). 
to divide the study area into four parts (Fig.8b). The result, high potential area accounts for $2.5 \%$ of the

study area with 2 known Au occurences contained, moderate potential area accounts for $16.1 \%$ of the study area with 3, low potential area accounts for $38.4 \%$ of the study area with 1 and low potential area accounts for $43 \%$ of the study area with none, would be an ideal metallogenic prediction map.

Although there was a known Au occurrence located in the low potential area, we noticed it was so close to the moderate potential area. This may be attribute to the substitution of point position for area projection. This Au occurrence was, acturally, an alteration zone about $0.76 \mathrm{~km}$ in length with a trend near east-west, while projected only its center on the horizontal. Therefore, it can be seen from the prospectivity map that the gold occurrence is away from the favorable metallogenic area less than 2 cells (400). In reality, the gold occurrence was partially contained by the moderate areas.
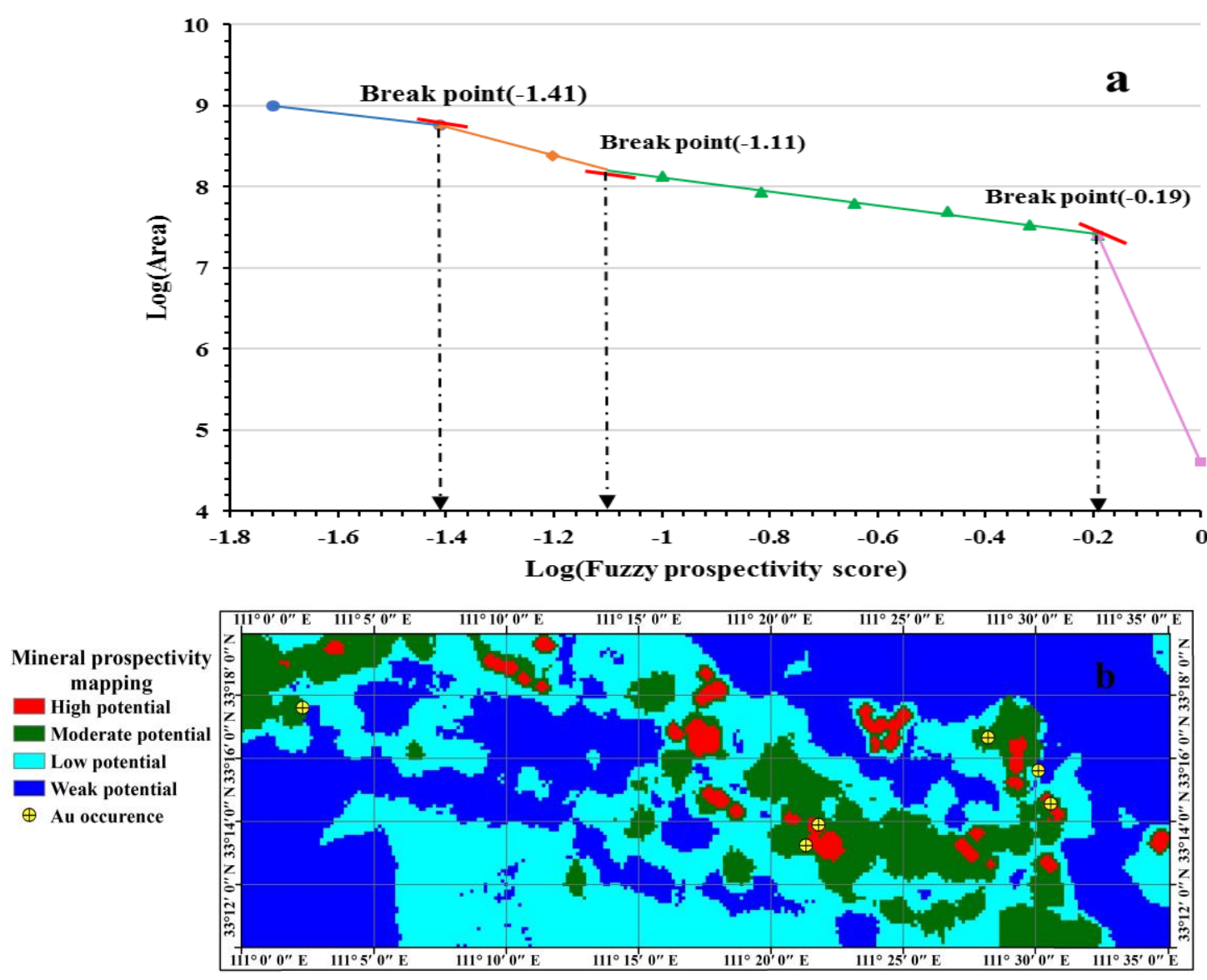

Fig.8. (a) Concentration-Area (C-A) model and (b) prospectivity map generated by Fig.5b. 


\section{Discussion}

Different evidence layers cannot be directly compared and integrated when used for mineral prospectivity mapping because of their different dimensions. Data-driven based logistic function, which is able to transform the evidence values of different magnitude into fuzzy values with the range of $0-1$ so as to represent their relative importance of mineralization, could be a suitable means. There is an assumption in this process that the largest and smallest evidence values are set a fuzzy score close to 1 $(0.99)$ and close to $0(0.01)$, respectively. This assumption is based on practical experience, in which experts assign weight to evidence values in fuzzy prospective predictions (Yousefi and Nykänen, 2016). importance of evidence values.

In this paper, a total of 4 fuzzy layers of geology and geochemistry were evaluated by P-A plot. The results demonstrate that the heat source possess the highest prediction rate, which is consistent with the strong control of orogenic gold deposits by geological hydrothermal. The prediction rate of faults also reaches $61 \%$, which has obvious positive correlation of mineralization. At the same time, both the two multi-element geochemistry 1 evidence layers have a prediction rates greater than $65 \%$, which is in line with the SFA analysis.

When overlying, a fuzzy gamma operation is used with a recommended value of 0.95 (BonhamCarter, 1995). The results revealed that the heat source, $\mathrm{Au}-\mathrm{As}-\mathrm{Pb}$ factor and $\mathrm{Cu}-\mathrm{Zn}-\mathrm{Mo}-\mathrm{Cd}$ factor had a relatively high prediction rate, which was then integrated to get a perspectivivity map with a maximum prediction rate of $83 \%$. This is higher than each of the evidence layers or integrating all of them. However, the prediction ability from Fig.5a to $5 \mathrm{c}$ has a tendency of going up first and declining latter. We wonder whether there would be a specific prediction rate, elevates the final prediction ability with evidence layer 
integrated over it and vice versa.

\section{Conclusions}

(1)The data-driven based logistic function has an excellent ability of converting evidence values of different scales into fuzzy scores with a range of $0-1$, and the relative importance of the obtained fuzzy scores are approximately in line with the original evidence values. Meanwhile, Due to the fact of reducing the influence of subjective preferences, data-driven based logistic function has abetter prediction effect than that of traditional knowledge-driven method.

(2) In this paper, the data-driven logistic function and the P-A evaluation were jointly applied to mineralization prediction. The result, heat source P-A plot has the highest predictive ability (81\%), indicating the strong correlation between mineralization and the intermediate-acid intrusive rock (vein), which is in line with the general characteristics of orogenic gold deposits.

(3) The mineralization prediction map was generated for the study area. The metallogenic target spread roughly along the northwest - southeast (consistent with the regional tectonic), which shows the high correlation between gold mineralization and tectonic activities, and provides guidance for further large-scale exploration .

\section{Acknowledgements}

This study was supported by the National Natural Science Foundation of China(Nos. U1903207, 41972176 and 41872248) as well as A Project Funded by the Priority Academic Program Development of Jiangsu Higher Education Institutions. The authors would like to thank Professor Mahyar Yousefi for his patient guidance. We also express special thanks to Dr. Du Xishihui for her warm suggestions. We appreciate the anonymous reviewers for their constructive comments. 


\section{References}

Abedi M, Norouzi, G.H., Fathianpour, N., 2013. Fuzzy outranking approach: A knowledge-driven method for mineral prospectivity mapping. International Journal of Applied Earth Observation and Geoinformation 21,556-567.

Abedi M., Norouzi, G.H., Bahroudi, A., 2012. Support vector machine for multi-classification of mineral prospectivity areas. Computers \& Geosciences 46, 272-283.

Behera S., Panigrahi M. K., Pradhan A., 2019. Identification of geochemical anomaly and gold potential mapping in the Sonakhan Greenstone belt, Central India: An integrated concentration-area fractal and fuzzy AHP approach. Applied Geochemistry 107, 45-57.

Billa, M., Cassard, D., Lips, A.L.W., Bouchot, V., Touliere, B., Stein, G., Guillou-Frottier, L., 2004. Predicting gold-rich epithermal and porphyry systems in the central Andes with a continental-scale metallogenic GIS. Ore Geology Reviews 25, 39-67.

Bonham-carter G. F. 1995. Geographic Information Systems for Geoscientists: Modelling with GIS. Computer Methods in the Geosciences 13. Pergamon Press, New York.

Bonham-Carter G.F., 1995. Geographic Information Systems for Geoscientists: Modelling with GIS. Computer Methods in the Geosciences 13. Pergamon Press, New York.

Bureau of geology and mineral resources of Henan province, 1989. Regional Geology records of Henan province.geological press, Beijing(in Chinese with English abstract).

C., Groves, D.I., Ojala,V.J., Eilu,P., Gardoll,S.J., 2008. Reconnaissancescale conceptual fuzzy-logic prospectivity modeling for iron oxide copper-gold de-posits in the northern Fennoscandian Shield,Finland. Australian Journal of Earth Sciences 55, 25-38.

Carlson, C.A., 1991. Spatial distribution of ore deposits. Geology 19, 111-114. 
Carranza, E. J. M., 2008. Geochemical anomaly and mineral prospectivity mapping in GIS. In Handbook of exploration and environmental geochemistry (Vol. 11, p. 351). Amsterdam: Elsevier.

Carranza, E.J.M., 2010. Improved wildcat modeling of mineral prospectivity. Resource Geology 60, 129149.

Carranza, E.J.M., Hale, M., 2001. Geologically-constrained fuzzy mapping of gold mineralization potential, Baguio district, Philippines. Natural Resources Research 10,125-136.

Carranza, E.J.M., Hale, M., 2002. Wildcat mapping of gold potential, Baguio district, Philippines. Transactions of the Institutions of Mining and Metallurgy, Section B: Applied Earth Science 111, 100-105.

Carranza, E.J.M., Hale, M., Faassen, C., 2008a. Selection of coherent deposit-type locations and their application in data-driven mineral prospectivity mapping. Ore Geology Reviews 33, 536-558.

Carranza, E.J.M., Laborte, A.G., 2015. Random forest predictive modeling of mineral prospectivity with small number of prospects and data with missing values in Abra (Philippines). Computers \& Geosciences 74, 60-70.

Carranza, E.J.M., van Ruitenbeek, F.J.A., Hecker, C., van der Meijde, M., van der Meer, F. D., 2008b. Knowledge-guided data-driven evidential belief modeling of mineral prospectivity in Cabo de Gata, SE Spain. International Journal of Applied Earth Observation and Geoinformation 10, 374-387.

Cassard, D., Billa, M., Lambert, A., Picot, J.C., Husson, Y., Lasserre, J.L., Delor, C., 2008. Gold predictivity mapping in French Guiana using an expert-guided data-driven approach based on a regional-scale GIS. Ore Geology Reviews 34, 471-500.

Chen D., Wei J., Wang W., Shi W., Li H., Zhan X., 2019. Comparison of Methods for Determining the Thresholds of Geochemical Anomalies and the Prospecting Direction-A Case of Gold Deposits in 
the Gouli Exploration Area, Qinghai Province. Mineral 9(6), 368; doi:10.3390/min9060368.

381 Chen, Y., Pirajno F., Qi J., 2008. The Shanggong gold deposit, Eastern Qinling Orogen, China: Isotope geochemistry and implications for ore genesis. Journal of Asian Earth Sciences 33:252-266.

Cheng Q., Agterberg, F.P., Ballantyneb S.B., 1994. The separation of geochemical anomalies from background by fractal methods. Journal of Geochemical Exploration C 51, 109-130.

Cheng, Q., Agterberg, F.P., 1999. Fuzzy weights of evidence and its application in mineral potential mapping. Natural Resources Research 8, 27-35.

Cheng, Q., Agterberg, F.P., Bonham-Carter, G.F., 1996. Fractal pattern integration for mineral potential estimation. Nonrenewable Resources 5, 117-130.

Chung, C.F., Fabbri, A.G., 1993. The representation of geoscience information for data integration.

Craw, D., Begbie, M., MacKenzie, D., 2006. Structural controls on Tertiary orogenic gold mineralization during initiation of a mountain belt, New Zealand. Mineralium Deposita 41(7), 645-659.

Du X., Zhou K., Cui Y., Wang J., Zhang N., Sun W., 2016. Analytical hierarchy process (AHP) and prediction-area (P-A) plot for mineral prospectivity mapping: a case study from the Dananhu

Ford, A., Blenkinsop, T.G., 2008. Combining fractal analysis of mineral deposit clustering with weights of evidence to evaluate patterns of mineralization: application to copper deposits of the Mount Isa

Ford, A., Miller, J.M., Mol, A.G., 2016. A comparative analysis of weights of evidence, evidential belief functions, and fuzzy logic for mineral potential mapping using incomplete data at the scale of 
Goldfarb, R.J., Groves, D.I., Garwin S., 2001. Orogenic gold and geologic time: a global synthesis. Ore Geology Reviews 18, 1-75.

Groves, D.I, Goldfarb, R.J., Gebre-Mariam, M., Hagemann, S.G., Robert, F., 1998. Orogenic gold deposits: A proposed classification in the context of their crustal distribution and relationship to other gold deposit types. Ore Geology Reviews 13, 7-27.

Groves, D.I., Goldfarb, R.J., Knox-Robinson, C.M., Ojala, J., Gardoll, S., Yun, G.Y., Holyland, P., 2000. Late-kinematic timing of orogenic gold deposits and significance for computer-based exploration techniques with emphasis on the Yilgarn Block, Western Australia. Ore Geology Reviews 17, 1-38.

Hengl T., 2006. Finding the right pixel size. Computers \& Geosciences 32, 1283-1298.

Herbert, S., Woldai, T., Carranza, E.C.M., van Ruitenbeek, F.J.A., 2014. Predictive mapping of prospectivity for orogenic gold in Uganda. Journal of African Earth Sciences 99, 666-693.

Hodkiewicz, P.F., Weinberg, R.F., Gardoll, S.J., Groves, D.I., 2005. Complexity gradients in the Yilgarn $1-68$. accretionary tectonic regimes. Geology 18 (9), 882-885. mapping, with reference to the orogenic gold mineralisation potential of the Kalgoorlie Terrane, 
Liu Y, Cheng Q, Xia Q, Wang X, 2014. Mineral potential mapping for tungsten polymetallic deposits in the Nanling metallogenic belt, South China. Journal of Earth Science 25, 689-700.

Liu Y, Cheng Q, Xia Q, Wang X, 2015. The use of evidential belief functions for mineral potential mapping in the Nanling belt, South China. Frontiers of Earth Science 9, 342-354.

Luo, J., 1990. Statistical mineral prediction without defining a training area. Mathematical Geology 22, 253-260.

Luo, X., Dimitrakopoulos, R., 2003. Data-driven fuzzy analysis in quantitative mineral resource

Pirajno, F., 2010. Intracontinental strike-slip faults, associated magmatism, mineral systems and mantle 
Porwal, A., Carranza, E.J.M., Hale, M., 2003a. Artificial neural networks for mineral potential mapping: A case study from Aravalli Province, Western India. Natural Resources Research 12, 155-171.

Porwal, A., Carranza, E.J.M., Hale, M., 2003b. Extended weights-of-evidence modelling for predictive mapping of base metal deposit potential in Aravalli province, western India. Exploration and Mining Geology 10(4), 273-287.

Porwal, A., Carranza, E.J.M., Hale, M., 2004. A hybrid neuro-fuzzy model for mineral potential mapping. Mathematical Geology 36, 803-826.

Porwal, A., Carranza, E.J.M., Hale, M., 2006. A hybrid fuzzy weights-of-evidence model for mineral potential mapping. Natural Resources Research 15, 1-14.

Raines, G.L., 2008. Are fractal dimensions of the spatial distribution of mineral deposits meaningful? Natural Resources Research 17, 87-97.

Roy, R., Cassard, D., Cobbold, P.R., Rossello, E.A., Billa,M., Bailly, M., Lips, A.L.W., 2006. Predictive

The second geology prospecting institute of Henan bureau of geology and mineral exploration and development, 2015. 1: 50,000 mineral prospect survey report of Bailang, Jingziguan, Xixia, Qiyu, 

Geochemical Exploration 198, 71-81.

Yousefi, M. 2017.Recognition of an enhanced multi-element geochemical signature of porphyry copper deposits for vectoring into mineralized zones and delimiting exploration targets in Jiroft area, SE Iran. Ore Geology Reviews 83, 200-214.

Yousefi, M., Carranza E.J.M., 2015a. Fuzzification of continuous-value spatial evidence for mineral prospectivity mapping. Computers \& Geosciences 74, 97-109.

Yousefi, M., Carranza E.J.M., 2015b. Prediction-area (P-A) plot and C-A fractal analysis to classify and evaluate evidential maps for mineral prospectivity modeling. Computers \& Geosciences 79, 69-81.

Yousefi, M., Carranza E.J.M., 2016. Data-driven index overlay and boolean logic mineral prospectivity modeling in greenfields exploration. Natural Resources Research 25, 3-18. of stream sediment geochemical anomalies for mineral potential mapping. Journal of Geochemical Exploration 128, 88-96.

Yousefi, M., Kamkar-Rouhani, A., Carranza, E.J.M., 2012. Geochemical mineralization probability Exploration 115, 24-35.

Yousefi, M., Kamkar-Rouhani, A., Carranza, E.J.M., 2014. Application of staged factor analysis and logistic function to create a fuzzy stream sediment geochemical evidence layer for mineral prospectivity mapping. Geochemistry: Exploration, Environment, Analysis 14, 45-58. 

103005, https://doi.org/10.1016/j.oregeorev.2019.103005.

Yousefi, M., Nykänen V., 2016. Data-driven logistic-based weighting of geochemical and geological evidence layers in mineral prospectivity mapping. Journal of Geochemical Exploration 164, 94-106. 